\title{
„UPORZĄDKUJCIE WE MNIE MILOŚĆ” (PNP 2, 4, LXX) W EGZEGEZIE WYBRANYCH AUTORÓW WSCHODU I ZACHODU
}

Kryzys emigracyjny, z jakim od pewnego czasu zmaga się Europa, sprawił, że już nie tylko moraliści, ale również politycy i publicyści, raz po raz odwołują się do zasady „porządku miłości” (ordo caritatis), wedle której jak tłumaczą - dobro własnego narodu powinno stać zawsze wyżej niż dobro innych narodów ${ }^{1}$. Ponieważ sama zasada ordo caritatis ma korzenie biblijne, warto zastanowić się jak była rozumiana przez Ojców Kościoła, a przy okazji dowiedzieć się, czy w poglądach na ten temat istniała jakaś różnica między przedstawicielami Wschodu i Zachodu.

Spośród biblijnych wersetów stanowiących podstawę ordo caritatis wybraliśmy jeden, z Pieśni nad Pieśniami, w jej greckim przekładzie. W księdze tej, jak wiadomo, zagadnienie miłości jest tematem centralnym: sam utwór zresztą to poemat miłosny oparty na dialogu Oblubieńca, Oblubienicy i chóru dziewcząt. Dodatkowo, Pieśń nad Pieśniami doczekała się w epoce patrystycznej wielu komentarzy, od Hipolita po Będę Czcigodnego ${ }^{2}$, można się więc spodziewać, że również interesujący nas werset został przez Ojców Kościoła szeroko omówiony. Konkretnie chodzi nam o słowa pojawiające się na początku tej księgi, gdzie Oblubienica prosi najpierw, by wprowadzić ją

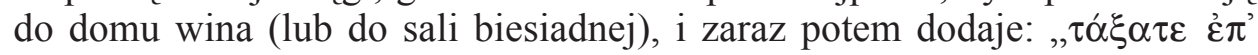

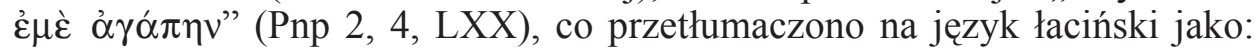
„ordinate in me caritatem” (,uporządkujcie we mnie miłość). Jak słowa te rozumiano na Wschodzie i na Zachodzie postaramy się prześledzić na podstawie wypowiedzi kilku wybranych autorów, trzech greckich: Orygenesa, Grzegorza z Nyssy i Teodoreta z Cyru, oraz trzech łacińskich: Augustyna, Jana Kasjana i Apponiusza.

\footnotetext{
* Ks. dr Arkadiusz Nocoń - professore invitato na Pontificia Università Gregoriana w Rzymie, pracownik watykańskiej Kongregacji Kultu Bożego i Dyscypliny Sakramentów; e-mail: narcadio@ yahoo.it.

${ }^{1}$ Por. np. A. Bartoszek, Porzadek w miłości, „Gość Niedzielny” 93 (2016) nr 27, 29.

2 Por. M. Starowieyski, Tradycje biblijne, Kraków 2011, 250. Szczegółowy wykaz autorów chrześcijańskich, który komentowali tę księgę podaje K. Bardski, Duchowa interpretacja Pieśni nad Pieśniami w tradycji żydowskiej i chrześcijańskiej, CT 78 (2008) nr 4, 107-108.
} 


\section{AUTORZY GRECCY}

1. Orygenes. Pierwszym teologiem, który podjął się egzegezy Pieśni nad Pieśniami był żyjący w pierwszej połowie III w. Hipolit: nie przypisał on jednak wersetowi Pnp 2, 4 większego znaczenia ${ }^{3}$. Historia interpretacji tego wersetu rozpoczyna się więc wraz z Orygenesem († ok. $254^{4}$ ), który był zarazem najwybitniejszym komentatorem tej księgi poświęcając jej swój komentarz i homilie 6 . Te ostatnie, wygłoszone ok. roku 240, prawdopodobnie w Cezarei, przeznaczone były dla ludzi rozpoczynających dopiero życie duchowe. Do naszych czasów zachowały się niestety tylko dwie z nich, w thumaczeniu Hieronima. Na samym początku 2. homilii Orygenes pisze:

„Twórca wszechrzeczy, Bóg, wszelkie poruszenia duszy stworzył dla dobra, jednakże na skutek naszego działania zdarza się często, że rzeczy z natury swej dobre, jeśli ich źle używamy, wiodą nas do grzechów. Jednym z poruszeń duszy jest miłość; posługujemy się nią dobrze, dla miłowania, jeśli kochamy mądrość i prawdę; kiedy zaś miłość nasza zwróci się ku gorszemu, wówczas kochamy ciało i krew"'.

Aleksandryjczyk nazywa tutaj ludzką miłość „rzeczą z natury swej dobrą”, której często, niestety, można używać źle ${ }^{8}$. Jako przykład poda miłość mężów do żon: może ona podobać się Bogu, ale może też być „haniebna”. Bardzo ważna jest więc kwestia uporządkowanej miłości, której w 2. homilii poświęci niemal cały ósmy rozdział. Słowa „Wprowadźcie mnie do domu wina, uporządkujcie we mnie miłość" (Pnp 2, 4, LXX), rozumie tutaj jako słowa Oblubieńca (Chrystusa), który zwraca się do Oblubienicy (będących jeszcze na drodze do doskonałości i do katechumenów), aby napełniła swą duszę ,winem wesela, winem Ducha Świętego" i wprowadziła Oblubieńca do swego domu ${ }^{10}$. Tylko On jeden może bowiem uporządkować miłość:

${ }^{3}$ Por. K.S. Frank, Geordnete Liebe. Cant 2,4b in der patristischen Auslegung, „Wissenschaft und Weisheit" 49 (1986) 15.

${ }^{4}$ Daty śmierci Ojców Kościoła podajemy według: F. Drączkowski, Patrologia, Pelplin - Lublin 1998.

${ }^{5}$ Por. Origenes, Commentarium in Canticum canticorum, éd. L. Brésard - H. Crouzel - M. Borret, SCh 375-376, Paris 1991-1992, thum. S. Kalinkowski, w: Orygenes, Komentarz do „Pieśni nad Pieśniami”. Homilie o „Pieśni nad Pieśniami”, Kraków 1994, 7-189.

${ }^{6}$ Por. tenże, Homiliae in Canticum canticorum, éd. O. Rousseau, SCh 37bis, Paris $2007^{2}$, thum. S. Kalinkowski, w: Orygenes, Komentarz do „Pieśni nad Pieśniami”. Homilie o „Pieśni nad Pieśniami", s. 193-227.

${ }^{7}$ Tamże II 1, SCh 37bis, 104, Kalinkowski, s. 210.

${ }^{8} \mathrm{Na}$ temat miłości u Orygenesa, zob. H. Pietras, L'amore in Origene, SEA 28, Roma 1988 (na stronach 133-138 autor omawia naukę Aleksandryjczyka nt. „miłości uporządkowanej”).

${ }^{9}$ Por. Origenes, In Canticum canticorum hom. 2, 1, SCh 37bis, 104, thum. Kalinkowski, s. $210-211$.

${ }^{10}$ Por. tamże II 8, SCh 37bis, 126-128, thum. Kalinkowski, s. 219. 
„Wszak miłość wielu jest nieuporządkowana: to, co powinni miłować w pierwszym rzędzie, miłują w drugiej kolejności, a to, co mają kochać w drugiej kolejności, miłują najpierw; to znów, co mają kochać na trzecim miejscu, kochają w czwartej kolejności, a to, co w czwartej, kochają w trzecim rzędzie; i w ten sposób w wielu ludziach miłość jest zamotana"11.

Orygenes wyraźnie zawraca tutaj uwagę na właściwą kolejność w ludzkim miłowaniu: jej przestrzeganie jest dla niego warunkiem porządku. Wyjaśnia też od razu, na czym owa kolejność polega:

„Słowo Boże życzy sobie, żebyś kochał ojca, syna, córkę; chce też, żebyś kochał Chrystusa, ale nie mówi ci, byś nie miłował dzieci, byś nie wiązał się miłością do rodziców. Cóż więc mówi? Niechaj miłość twoja nie będzie nieuporządkowana tak, iżbyś nie kochał najpierw ojca i matki, a dopiero potem Mnie; aby nie ogarnęła cię miłość do syna i córki bardziej niż miłość do Mnie. «Kto kocha ojca lub matkę bardziej niż Mnie, nie jest Mnie godzien. I kto kocha syna lub córkę bardziej niż Mnie, nie jest Mnie godzien» (Mt 10, 37)"'12.

Bóg, Chrystus, powinien więc być zawsze na pierwszym miejscu, a po Nim?

„Aby jednak po Bogu został też ustalony porządek miłości między nami, wydano najpierw polecenie, byśmy kochali rodziców, po wtóre - byśmy kochali dzieci, po trzecie - byśmy kochali domowników. Jeśli jednak syn jest zły, a domownik dobry, wówczas domownika należy miłować tak jak syna"13.

Po tym sprecyzowaniu wyjaśnia czym różni się miłość do Boga, do bliskich i do nieprzyjaciół:

„«Będziesz miłował Pana Boga twego całym swoim sercem, całą swoją duszą, wszystkimi swymi siłami, całym swoim umysłem. Będziesz miłował bliźniego swego jak siebie samego» (Mt 22, 37. 39). Nie mówi: «Będziesz miłował Boga jak siebie samego, a bliźniego całym sercem, całą duszą, całą mocą, całym umysłem». Mówi też dalej: «Miłujcie nieprzyjaciół waszych» (Mt 5, 44), ale nie dodaje: «całym sercem». Nauka Boża nie jest nieuporządkowana, nie daje niewykonalnych przykazań, nie mówi: «Miłujcie nieprzyjaciół waszych jak samych siebie», lecz tylko: «Miłujcie nieprzyjaciół waszych». Wystarczy im, że ich miłujemy i nie nienawidzimy; bliźniego zaś - «jak siebie samego», a Boga - «całym sercem, całą duszą, całym umysłem, ze wszystkich sił»"14.

Homilie o „Pieśni nad Pieśniami” przeznaczone były, jak wspomnieliśmy, dla rozpoczynających dopiero życie duchowe, stąd może dlatego Orygenes przedstawia w nich tylko szkic ,,porządku miłości”. Co z niego wynika? Że miłość, ,rzecz” z natury swej dobra, może być przez człowieka używana

\footnotetext{
${ }^{11}$ Tamże II 8, SCh 37bis, 128, thum. Kalinkowski, s. 219.

12 Tamże.

${ }^{13}$ Tamże, SCh 37bis, 130, tłum. Kalinkowski, s. 220.

${ }^{14}$ Tamże.
} 
źle i prowadzić do grzechu. Bóg przekazał więc człowiekowi zasady „porządku miłości”, których przestrzeganie pozwala osiągnąć świętość (miłość świętych jest zawsze uporządkowana). Zasady te mówią ogólnie, kogo i jak należy kochać. W przypadku „kogo”, Orygenes wymienia poszczególne kręgi osób, przypisując im, w oparciu o cytaty z Ewangelii, odpowiednią intensywność uczucia (,jak"). Na pierwszym miejscu, człowiek zawsze więc powinien kochać Boga (,całym sercem, całą duszą, całym umysłem”), a na drugim, bliźniego (,jak siebie samego"). W przypadku miłości bliźniego Orygenes nie traktuje jednak wszystkich jednakowo: rodzice, żona, dzieci, mają u niego pierwszeństwo przed innymi domownikami. „Porządek miłości” obejmuje również nieprzyjaciół, a miłość wobec nich polega na wyzbyciu się nienawiści.

Ta nauka Aleksandryjczyka zostanie rozwinięta w Komentarzu do „Pieśni nad Pieśniami”, powstałym w tym samym czasie, co homilie (ok. 240), ale przeznaczonym dla ludzi zaawansowanych już w życiu duchowym. Tekst komentarza, podobnie jak homilii, dotarł do naszych czasów tylko częściowo, w łacińskim tłumaczeniu Rufina.

Interpretując werset Pnp 2, 4, LXX, Orygenes już na samym początku zaskakuje: jeśli bowiem w homiliach słowa: „Wprowadźcie mnie do domu wina, uporządkujcie we mnie miłość", wypowiada Oblubieniec (Chrystus), do Oblubienicy (rozpoczynających drogę do doskonałości), to w komentarzu mówi je Oblubienica (,Kościół Chrystusowy, czy też dusza tkwiąca przy Słowie Bożym”) ${ }^{15}$, do przyjaciół i towarzyszy Oblubieńca ${ }^{16}$ (tych, co „od początku świata głosili Słowo Boże" ${ }^{17}$ : proroków, apostołów ${ }^{18}$, świętych ${ }^{19}$, aniołów ${ }^{20}$ ). Oblubienica pragnie tutaj „nasycić się [ich] naukami mądrości i tajemnicami wiedzy, niby rozkosznymi pokarmami i wspaniałym winem" "21, i otrzymać od nich ,pouczenie o całym porządku i sensie miłości”"22, aby z tej strony (miłości) „nie doznać rany”23.

Swoje rozważanie na temat „porządku miłości” Orygenes rozpoczyna od konstatacji, że każdy człowiek, po osiągnięciu wraz z wiekiem zdolności kochania, skłania ku komuś lub ku czemuś swoje serce ${ }^{24}$. Problem w tym, że „u niewielu tylko ludzi [miłość] toczy się w odpowiednim i stosownym porządku"25, większość kocha bowiem coś, czego nie powinna, a jeśli już kocha

\footnotetext{
${ }^{15}$ Por. tenże, In Canticum canticorum comm. III 6, 1-2, SCh 376, 540, tłum. Kalinkowski, s. 133.

${ }^{16}$ Por. tamże III 6, 1, SCh 376, 540, thum. Kalinkowski, s. 133.

${ }^{17}$ Por. tamże III 6, 2, SCh 376, 540, tłum. Kalinkowski, s. 133.

${ }^{18}$ Por. tamże III 7, 1, SCh 376, 548, tłum. Kalinkowski, s. 135.

${ }^{19}$ Por. tamże III 7, 30, SCh 376, 564, thum. Kalinkowski, s. 140.

${ }^{20}$ Por. tamże III 7, 28, SCh 376, 562, thum. Kalinkowski, s. 140.

${ }^{21}$ Por. tamże III 6, 6, SCh 376, 542, thum. Kalinkowski, s. 134.

${ }^{22}$ Por. tamże III 7, 31, SCh 376, 564, thum. Kalinkowski, s. 141.

${ }^{23}$ Por. tamże III 7, 27, SCh 376, 562, thum. Kalinkowski, s. 140.

${ }^{24}$ Por. tamże III 7, 2, SCh 376, 548, thum. Kalinkowski, s. 135.

${ }^{25}$ Por. tamże.
} 
to, co powinna, to kocha w sposób nadmierny bądź niedostateczny, czyli nieuporządkowany ${ }^{26}$.

Drugą ważną przesłanką w jego rozważaniach na temat ,porządku miłości” jest rozróżnienie na „miłość ogólną i szczególną”. Tą pierwszą powinno się obejmować wszystkich ludzi, ponieważ jako istoty rozumne są do siebie podobni ${ }^{27}$. Tym niemniej:

,jeśli na przykład ktoś wyróżnia się charakterem, uczynkami, stawianymi sobie celami, wiedzą lub studiami, to stosownie do jego własnych zasług na tym polu należy do miłości ogólnej dodać jeszcze pewną miłość szczególną"28.

Przykład takiej miłości dał nam sam Bóg, który mimo, że kocha wszystko, co istnieje, i nie nienawidzi niczego, co stworzył, to jednak nie tak samo miłował Hebrajczyków i Egipcjan, Mojżesza i faraona ${ }^{29}$. Nie tak samo kochał św. Pawła, gdy prześladował on Kościół, jak wtedy, gdy troszczył się o wszystkie Kościoły $^{30}$. Skoro więc nawet Bóg ,wagę swojej miłości reguluje według miary zasług każdego człowieka”, uprawnione jest stosowanie takiej „wagi” w relacjach międzyludzkich, twierdzi Orygenes ${ }^{31}$, któremu bliżej w tym wypadku do obrazu Boga sprawiedliwego ze Starego Testamentu, niż do miłosiernego Ojca zsyłającego deszcz na sprawiedliwych i niesprawiedliwych (por. Mt 5, $45)^{32}$. Podobnie jak w homiliach Aleksandryjczyk wymienia następnie kręgi osób, które powinny być kochane miłością szczególną („kogo”) i podaje „miarę” tej miłości (,jak”). Na pierwszym miejscu należy więc kochać Boga - powtórzy - i miłość ta powinna być „bez żadnej miary”, czyli z całego serca, z całej duszy i z wszystkich sił (por. Mk 12, 30): jednym słowem, powinna oddawać Bogu wszystko, co posiada ${ }^{33}$. Na drugim miejscu należy kochać bliźniego, i to jak siebie samego (por. Mk 12, 31): w miłości tej jest więc już pewna miara ${ }^{34}$. Ten ogólny zarys ,,porządku miłości”, znany już z homilii, zostanie w komentarzu znacznie rozbudowany, głównie dlatego, że miłość bliźniego, zdaniem Orygenesa, ma wiele odcieni. Prawdą jest więc, jak uczył św. Paweł, że wszyscy ludzie są dla siebie nawzajem członkami (por. Ef 4, 25), i powinni odnosić się do siebie z miłością, ale ten sam Apostoł uczył też, że w jednym ciele są członki bardziej i mniej godne szacunku (por. 1Kor 12, 22), stąd również „stopień miłości powinien być mierzony stosownie do zasług i godności członków"35. Kogo Orygenes uważa za bardziej godnego szacunku

\footnotetext{
${ }^{26}$ Por. tamże III 7, 3, SCh 376, 548, thum. Kalinkowski, s. 135.

${ }^{27}$ Por. tamże III 7, 22, SCh 376, 558, thum. Kalinkowski, s. 138.

${ }^{28}$ Tamże.

${ }^{29}$ Por. tamże III 7, 23-24, SCh 376, 558-560, thum. Kalinkowski, s. 138-139.

${ }^{30}$ Por. tamże III 7, 25, SCh 376, 560, thum. Kalinkowski, s. 139.

${ }^{31}$ Por. tamże III 7, 24, SCh 376, 560, thum. Kalinkowski, s. 139.

${ }^{32}$ Por. H. Pétré, Ordinata caritas. Un enseignement d'Origène sur la charité, RSR 42 (1954) 50.

${ }^{33}$ Por. Origenes, In Canticum canticorum comm. III 7, 4, SCh 376, 550, thum. Kalinkowski, s. 135.

${ }^{34}$ Por. tamże.

${ }^{35}$ Por. tamże III 7, 6-7, SCh 376, 550-552, tłum. Kalinkowski, s. 136.
} 
od pozostałych? Niewątpliwie tych, którzy trudzą się głoszeniem Słowa Bożego, pouczają i oświecają ludzkie dusze, ukazując im drogę zbawienia - tych należy kochać miłością szczególną, w drugiej kolejności po Bogu ${ }^{36}$. Niemal na równi z nimi należy kochać tych, którzy nie mają wprawdzie „łaski pouczania, kształcenia albo głoszenia Słowa Bożego", ale są ludźmi wiodącymi świątobliwe życie, prawymi i czystymi - tych należy miłować ze względu na „dzieło" ich życia ${ }^{37}$, albowiem przyczyniają się do rodzenia innych w Chrystusie (por. 1 Kor 4,15$)^{38}$. Zaraz po nich powinno się miłować tych, z którymi łączą nas więzy krwi, a więc rodziców i rodzeństwo:

„Z większym szacunkiem należy okazywać miłość matce, a w drugiej kolejności, również z pewnym szacunkiem - siostrom. Zupełnie inaczej trzeba kochać żonę. W dalszej kolejności, stosownie do zasług i przyczyn, należy miłować każdego człowieka z zachowaniem czystości [...]. Podobnie możemy powiedzieć również o ojcu, bracie i o innych krewnych"39.

Specjalny status wśród najbliższych Orygenes nadaje żonie, którą „trzeba kochać zupełnie inaczej", niż wszystkie inne kobiety, bo jak własne ciało (por. Ef 5,28$)^{40}$, co nie wyklucza, by również względem innych kobiet (matek, sióstr, znajomych) „żywić czystą miłość”, mając na uwadze „pewne stopnie i stosowne różnice w miłości, którą otaczać należy różne kobiety”41.

Aleksandryjczyk zastanawia się również czy tak samo powinno się kochać rodziców i rodzeństwo, gdy są wierzący lub niewierzący:

„Również gdy chodzi o wierzących i niewierzących rodziców, braci i siostry - czyż może być tak, żeby im jednakową okazywano miłość? Oblubienica dostrzega te różnice i rozumie, że dążąca do doskonałości dusza powinna koniecznie posiąść wiedzę o tych wszystkich zagadnieniach, aby mogła zachować stosowną miarę miłości, zależnie od okoliczności; powiada więc do przyjaciół Oblubieńca, czyli do tych, którzy głoszą Słowo Boże: «Uporządkujcie we mnie miłość», to znaczy - pouczcie mnie i wyjaśnijcie, jaki w tych okolicznościach powinnam zachować porządek miłości”"42.

Rozbudowane jest także podejście Orygenesa do nieprzyjaciół. Jeśli w homiliach wspomniał tylko, że miłość do nich polega na wyzbyciu się nienawiści, w komentarzu uczy o stopniach miłości w zależności od ich postępowania:

„Załóżmy, że mam nieprzyjaciela, który jednak poza tym postępuje prawidłowo, jest skromny i trzeźwy, przestrzega większości przykazań Bożych,

\footnotetext{
${ }^{36}$ Por. tamże III 7, 9-10, SCh 376, 552, thum. Kalinkowski, s. 136.

${ }^{37}$ Por. tamże III 7, 12, SCh 376, 554, thum. Kalinkowski, s. 137.

${ }^{38}$ Por. tamże III 7, 19, SCh 376, 556-558, thum. Kalinkowski, s. 138.

${ }^{39}$ Tamże III 7, 18, SCh 376, 556, tłum. Kalinkowski, s. 138.

${ }^{40}$ Por. tamże III 7, 16-18, SCh 376, 556, thum. Kalinkowski, s. 137-138.

${ }^{41}$ Por. tamże III 7, 16-17, SCh 376, 556, thum. Kalinkowski, s. 137-138.

${ }^{42}$ Tamże III 7, 20-21, SCh 376, 558, tłum. Kalinkowski, s. 138.
} 
ale też popełnia pewne błędy, jak człowiek; i jest ktoś inny, kto również jest naszym nieprzyjacielem, ale jest przy tym nieprzyjacielem własnego życia, własnej duszy, gotów do popełnienia przestępstwa i zbrodni, dla którego nie ma żadnej świętości; czy nie sądzisz, że również tym nieprzyjaciołom należy okazywać miłość różnego stopnia?"43.

Podsumowując naukę o ,,porządku miłości” zawartą w Komentarzu do „Pieśni nad Pieśniami”, zauważamy, że autor odwołuje się tutaj do przykładu Boga, który choć kocha wszystkich ludzi, to jednak szczególną miłością otacza świętych i prawych. Wszyscy chrześcijanie, zaraz po Bogu, powinni więc miłować tych, którzy pomagają im w zbawieniu, a więc tych, którzy głoszą im Słowo Boże, upominają i budują swoim przykładem. Dopiero po nich Orygenes wymienia członków rodziny, co jest pewną nowością w stosunku do Homilii o „Pieśni nad Pieśniami”, gdzie jego nauka o uporządkowanej miłości koncentrowała się głównie na nich. Inną nowością komentarza jest również rozbudowane podejście do nieprzyjaciół.

W obydwu swych pismach Orygenes nie przeprowadza jednak jakiejś szczegółowej kazuistyki i nie roztrząsa tzw. „życiowych przypadków”, może poza jednym w homiliach, gdzie zastanawia się czy bardziej kochać dobrego domownika czy niedobrego syna, oraz jednym w komentarzu, gdzie rozważa jak powinna wyglądać miłość do żony na tle innych kobiet. Generalnie zależy mu jednak na ukazaniu pewnego problemu nieuporządkowanej miłości, z którym - w jego opinii - zmaga się większość ludzi, oraz na podaniu ogólnych zasad radzenia sobie $\mathrm{z}$ tym problemem. Jako remedium wskazuje tutaj wspólnotę z prorokami, apostołami, kapłanami i świętymi, czyli wspólnotę Kościoła, w której chrześcijanin, poprzez dążenie do świętości, uczy się przestrzegania ,porządku miłości",44.

2. Grzegorz z Nyssy. Powstałe mniej więcej 150 lat po komentarzu Orygenesa Homilie do Pieśni nad Pieśniami Grzegorza z Nyssy († 394) ${ }^{45}$ są pod wyraźnym wpływem tekstu Aleksandryjczyka, zarówno jeśli chodzi o metodę interpretacyjną, jak i samą treśćc ${ }^{46}$. Widać to również w egzegezie wersetu Pnp 2, 4, LXX gdzie, według Grzegorza, Oblubienica (dusza ludzka) zwraca się do przyjaciół Oblubieńca ${ }^{47}$, aby uporządkowali jej miłość, tzn. aby pouczyli ją ,jaką miłość kierować ku Bogu, a jaką mieć do ludzi”" Ny. Nysseńczyk,

${ }^{43}$ Por. tamże III 7, 13-14, SCh 376, 554, tłum. Kalinkowski, s. 137.

${ }^{44}$ Por. Frank, Geordnete Liebe, s. 21.

${ }^{45}$ Por. Gregorius Nyssenus, Homiliae in Canticum canticorum, ed. H. Langerbeck, GNO 6 , Leiden 1960, tłum. M. Przyszychowska: Grzegorz z Nyssy, Homilie do Pieśni nad Pieśniami, ŹMT 43, Kraków 2007.

${ }^{46}$ Por. M. Przyszychowska, Wstęp, w: Grzegorz z Nyssy, Homilie do Pieśni nad Pieśniami, s. 8-9.

${ }^{47}$ Por. Gregorius Nyssenus, In Canticum canticorum hom. 4, GNO 6, 117-118 i 123, ŹMT 43,74 i 76.

${ }^{48}$ Tamże, GNO 6, 121, ŹMT 43, 75. 
podobnie jak Orygenes, uważa bowiem, że „u wielu ludzi można zobaczyć miłość pomieszaną i nieuporządkowaną, która działa w sposób błędny i nie-

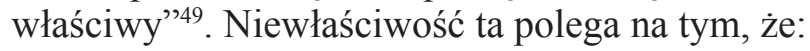

„są tacy, którzy kochają z całej duszy i wszystkich sił pieniądze, zaszczyty lub kobiety, darząc je cieplejszymi uczuciami, jakby chcieli oddać za nie własne życie, Boga [kochaja] jak im się podoba, a bliźniemu taką okazują miłość, jaką z trudem można przypisać wrogom. Z kolei wobec tych, którzy ich nienawidza, mają takie nastawienie, że za wyrządzone przykrości odpłacają jeszcze większym złem"50.

Warto zwrócić uwagę, że u Grzegorza, jako przedmioty pożądania i miłości, pojawiają się ,pieniądze i zaszczyty”, czego nie było u Orygenesa. Sam problem nieuporządkowanej miłości jest jednak dla Nysseńczyka równie ważny, gdyż:

,jeśli trzeba, by wszystko odbywało się porządnie i właściwie, to tym bardziej stosowny jest porządek w tych sprawach. Kain bowiem nie zostałby potępiony za to, że źle dzielił [rzeczy], gdyby wraz z właściwym złożeniem ofiary strzegł w porządku tego, co wypada, zarówno tego, co pozostawiał sobie dla [zaspokojenia] potrzeb, jak i tego, co ofiarował Bogu (por. Rdz 4, 7): powinien był ofiarować Bogu pierwociny, on jednak, nasyciwszy się co smakowitszymi kąskami, uczcił Boga resztkami"'51.

Nieprzestrzeganie ,porządku miłości” może mieć zatem tragiczne konsekwencje (potępienie), przypomina Grzegorz, aby się przed tym ustrzec, należy bezwzględnie przestrzegać przykazania miłości Boga i bliźniego (por. Mk 12, 30n), stanowiącego podstawę uporządkowanej miłości:

„Boga należy kochać z całego serca, duszy, sił i zmysłów, bliźniego jak siebie samego, żonę - jeśli ktoś jest czysty na duszy - jak Chrystus Kościół, a jeśli pełen namiętności - jak własne ciało (tak uczy Paweł, który układa te rzeczy we właściwym porządku (por. Ef 5, 24. 28), wroga tak, by nie oddawać zła za zło, ale za niesprawiedliwość odpłacać dobrocią (por. Rz 12, 17)”52.

W przeciwieństwie do Orygenesa, który uczył, że miłość do nieprzyjaciół polega na tym, aby ich nie nienawidzić5 ${ }^{3}$, bądź okazywać im „miłość różnego stopnia”, w zależności od ich postępowania ${ }^{54}$, Grzegorz z Nyssy, nawiązując wyraźnie do słów św. Pawła z Listu do Rzymian, każe odpłacać im dobrem za zło. Rozróżnia również między miłością do żony, gdy ktoś jest „czysty na

${ }^{49}$ Tamże, GNO 6, 122, ŹMT 43, 76.

${ }^{50}$ Tamże, GNO 6, 122-123, ŹMT 43, 76.

${ }^{51}$ Tamże, GNO 6, 121, ŹMT 43, 75.

${ }^{52}$ Tamże, GNO 6, 122, ŹMT 43, 75-76.

${ }^{53}$ Por. Origenes, In Canticum canticorum hom. II 8, SCh 37bis, 130, thum. Kalinkowski, s. 220.

${ }^{54}$ Por. tenże, In Canticum canticorum comm. III 7, 13-14, SCh 376, 554, thum. Kalinkowski, s. 137. 
duszy”, i gdy jest „pełen namiętności”. Można więc powiedzieć, że niektóre jego wymagania dotyczące „porządku miłości” są większe niż u Orygenesa, dlatego - jego zdaniem - dusza ludzka potrzebuje pomocy przyjaciół Oblubieńca, aby „Bogu zostało oddane to, co się należy, a we wszystkim innym nie została przekroczona właściwa miara" ${ }^{5}$.

3. Teodoret z Cyru. Kolejnym pisarzem chrześcijańskiego Wschodu, który Pieśni nad Pieśniami poświecił swój komentarz jest Teodoret z Cyru $(† 466)^{56}$. Idąc za Orygenesem interpretuje on miłość Oblubieńca do Oblubienicy jako alegorię miłości Chrystusa do Kościoła ${ }^{57}$. Interesującemu nas wersetowi Pnp 2, 4, LXX, Biskup Cyru poświęca jednak niewiele miejsca, stąd jego słowa można przytoczyć w całości. Oblubienica zwraca się w tym fragmencie do sług Oblubieńca:

„«Uporządkujcie we mnie miłość», to znaczy, nauczcie mnie jak mam kochać, abym nie kochała ojca lub matki, pola lub winnicy, bardziej niż Oblubieńca, i abym nie okazała się Jego niegodna. On sam bowiem powiedział: «Kto kocha ojca lub matkę bardziej niż Mnie, nie jest Mnie godzien. I kto kocha synów lub córki bardziej niż Mnie, nie jest Mnie godzien» (Mt 10, 37). Również dawne prawo, przekazane Adamowi, głosiło: «Dlatego to mężczyzna opuści ojca swego i matkę swoją i złączy się ze swą żoną tak ściśle, że staną się jednym ciałem» (Rdz 2, 24). A zatem «uporządkujcie we mnie miłość», abym złączyła się z moim Oblubieńcem i kochała Go bardziej aniżeli ojca, matkę, lub kogokolwiek innego" 58 .

Jest rzeczą interesująca, że Teodoret, chociaż sam był jednym z najwybitniejszych przedstawicieli tzw. antiocheńskiej szkoły egzegetycznej, komentował Pieśń nad Pieśniami w duchu post-orygenesowskich alegorystów, nie stroniąc od interpretacji ponaddosłownych ${ }^{59}$. W cytowanym fragmencie nie wychodzi on jednak poza obszar miłości Oblubieńca i Oblubienicy, i tylko do tej miłości odnosi swój ,porządek”, polegający na tym, a raczej przypominający to, że Oblubienica (synowie Kościoła), powinni kochać Oblubieńca (Chrystusa) bardziej niż kogokolwiek innego, nawet za cenę opuszczenia swoich bliskich. O uporządkowanej miłości chrześcijanina można więc mówić dopiero wtedy, gdy jest on doskonale zjednoczony z Chrystusem i stanowi z Nim, ,jedno ciało".

${ }^{55}$ Gregorius Nyssenus, In Canticum canticorum hom. 4, GNO 6, 123, ŹMT 43, 76.

${ }^{56}$ Por. Theodoretus Cyrensis, Commentarium in Canticum canticorum, PG 81, 27-214.

${ }^{57}$ Por. Drączkowski, Patrologia, s. 304.

${ }^{58}$ Theodoretus Cyrensis, In Canticum canticorum comm. I 2, PG 81, 89, thum. własne.

${ }^{59}$ Por. K. Bardski, ,Napoję cię winem korzennym, moszczem z granatów” (Pnp 8, 2b). Pragnienie Oblubieńca $w$ świetle starożytnych i średniowiecznych komentarzy do Pieśni nad Pieśniami, VV 5 (2004) 161. 


\section{AUTORZY ŁACIŃSCY}

1. Augustyn. Biskup Hippony $(\dagger 430)$ nie napisał osobnego komentarza do Pieśni nad Pieśniami, a samą księgę cytował rzadko. Niemniej jednak, jako autor zafascynowany ideą $o r d o^{60}$, przywołał kilka razy w swoich pismach werset Pnp 2, 4, LXX. Przykładowo w Mowie 21., głosząc pochwałę wszelkiego stworzenia oraz porządku w jakim wszystko zostało stworzone, powiedział wprost, że nie jest grzechem kochać to, co Bóg stworzył, lecz kochać w sposób nieuporządkowany, tzn. wbrew woli Stworzyciela ${ }^{61}$. Słowa „Uporządkujcie we mnie miłość" (Pnp 2, 4, LXX), oznaczają więc według niego, aby skłaniając się ku dobrom niższym nie zaniedbywać Dobra Najwyższego ${ }^{62}$. Podobne stwierdzenia pojawiają się w Mowie 37., w której Augustyn podkreślał, że pochodną wszelkiego porządku jest piękno (nihil pulchrius hoc ordine), stąd każda nieuporządkowana miłość byłaby dla niego nie tylko grzechem, ale i skazą na pięknie stworzenia ${ }^{63}$.

W Mowie 65A. odnosi werset Pnp 2, 4, LXX do więzi rodzinnych oraz do relacji człowieka do Boga. Osoby bliskie powinny być kochane zawsze i każdy brak miłości wobec nich jest grzechem ${ }^{64}$, tym niemniej, jest jednak Ktoś (Jezus Chrystus), kto powinien być kochany bardziej niż ojciec, matka, żona czy dzieci. Grzechem jest nie tylko kochać bliskich bardziej niż Jezusa, ale także kochać ich na równi z Nim, gdyż uporządkowana miłość polega na tym, że Stworzyciela i Zbawcę kochamy bardziej niż kogokolwiek ${ }^{65}$. Dotyczy to każdej sytuacji: miłość bliskich nie zwalnia więc nigdy chrześcijanina z obowiązku, gdy potrzeba, oddania życia za Jezusa ${ }^{66}$. Augustyn podkreśla tutaj mocno aspekt moralny ,porządku miłości”, nazywając każde uchybienie grzechem, prowadzącym nawet do potępienia ${ }^{67}$.

Temat wyboru między miłością do najbliższych a miłością do Jezusa, powraca w Mowie 100., gdzie Augustyn komentuje słowa Jezusa skierowane do spotkanego młodzieńca: „Zostaw umarłym grzebanie ich umarłych, a ty idź i głoś królestwo Boże!” (Łk 9, 60). Dla Biskupa Hippony nie ulega i tutaj wątpliwości, że posłuszeństwo Jezusowi ważniejsze jest niż przykazanie miłości rodziców zawarte w czwartym przykazaniu Dekalogu ${ }^{68}$. „Cóż oznaczają słowa: «Uporządkujcie we mnie miłość» (Pnp 2, 4, LXX)?" - pyta i zaraz odpowiada: „Ustalcie stopnie [miłości] i dajcie każdemu taką jaka mu się

\footnotetext{
${ }^{60}$ Por. Pétré, Ordinata caritas, s. 53.

${ }^{61}$ Por. Augustinus, Sermo 21, 3, ed. M. Pellegrino - L. Cruciani - V. Tarulli - F. Monteverde, NBA 29, Roma 1979, 398.

${ }^{62}$ Por. tamże.

${ }^{63}$ Por. tenże, Sermo 37, 23, NBA 29, 684.

${ }^{64}$ Por. tenże, Sermo 65A, 8, ed. L. Carrozzi, NBA 30/1, Roma 1982, 332.

${ }^{65}$ Por. tamże 65A, 11, NBA 30/1, 334.

${ }^{66}$ Por. tamże 65A, 9-10, NBA 30/1, 332-334.

${ }^{67}$ Por. tamże 65A, 8, NBA 30/1, 332.

${ }^{68}$ Por. tenże, Sermo 100, 1. 2, ed. L. Carrozzi - F. Monteverde, NBA 30/2, Roma 1983, 232.
} 
należy. Nie stawiajcie niżej tego, co powinno stać wyżej. Kochajcie rodziców, ale ponad rodziców kochajcie Boga"69.

Jeszcze raz problem ten podejmie w Mowie 344. komentując słowa: „Kto kocha ojca lub matkę bardziej niż Mnie, nie jest Mnie godzien” (Mt 10, 37):

„Bóg nie zniósł miłości do rodziców, do żony, do dzieci, ale ją uporządkował. Nie powiedział bowiem: «Kto kocha ojca...», ale «Kto bardziej niż Mnie kocha ojca...». To o tym właśnie mówi Kościół w Pieśni nad Pieśniami, gdy stwierdza: «Uporządkował we mnie miłość» (Pnp 2, 4, LXX). Kochaj więc ojca, ale nie kochaj go bardziej niż Pana; kochaj tego, kto cię zrodził, ale nie bardziej od Tego, kto cię stworzył. [...] Kochaj twoją matkę, ale nie bardziej niż Kościół, który cię zrodził do życia wiecznego"70.

Dla Augustyna, jak widzimy, nie ulega wątpliwości, że tak jak życie wieczne ważniejsze jest od życia ziemskiego, tak miłość do Boga i Kościoła ważniejsza jest od miłości do członków rodziny. W tej samej Mowie powtórzy jeszcze, że gdyby najbliżsi próbowali kogoś odwieść od męczeństwa za wiarę, by ocalić go dla siebie, powinni pamiętać, że tylko zjednoczenie z Jezusem gwarantuje im ,bycie razem”, a zdrada Jezusa rozdziela ich na wieki ${ }^{71}$.

Poza mowami werset Pnp 2, 4, LXX pojawia się jeszcze u Augustyna w Państwie Bożym ${ }^{72}$, gdzie zauważa on, iż na skutek wolnej woli człowiek może kochać dobrze lub źle, w zależności od tego czy jego miłość zachowuje porządek $^{73}$, będący również warunkiem cnoty:

„Wydaje mi się przeto, że krótkie a trafne określenie cnoty brzmi: cnota jest to uporządkowana miłość. Dlatego w świętej Pieśni nad Pieśniami oblubienica Chrystusowa, czyli państwo Boże śpiewa: «Uporządkujcie we mnie miłośćı" (Pnp 2, 4, LXX)"74.

Ta uporządkowana miłość ma zaś miejsce wtedy, gdy najpierw kocha się Boga, dobro duchowe i wieczne, a potem stworzenia, dobra cielesne i doczesne $^{75}$. Tylko zachowując ten ,porządek” miłość staje się cnotą, w każdym innym przypadku jest grzechem. Warto o tym pamiętać, gdyż często nadużywa się słynnych słów Augustyna: „dilige, et quod vis fac”"76, wedle których miłość

${ }^{69}$ Tamże 100, 2, NBA 30/2, 232, tłum. własne.

70 Tenże, Sermo 344, 2, ed. V. Paronetto - A.M. Quartiroli - F. Monteverde, NBA 34, Roma 1989, 54-56, tłum. własne.

${ }^{71}$ Por. tamże, NBA 34, 56.

${ }^{72}$ Por. tenże, De civitate Dei libri XXII, ed. A. Trapè - R. Russell - S. Cotta - D. Gentili, NBA 5/1, Roma 1978, ed. D. Gentili - A. Trapè, NBA 5/2, Roma 1988, tłum. W. Kornatowski: Święty Augustyn, O państwie Bożym. Przeciw poganom ksiag XXII, t. 1-2, Warszawa 1977.

${ }^{73}$ Por. tamże 15, 22, NBA 5/2, 436-438, tłum. Kornatowski, t. 2, s. 201.

74 Tamże 15, 22, NBA 5/2, 438, tłum. Kornatowski, t. 2, s. 201-202.

75 Por. tamże, tłum. Kornatowski, t. 2, s. 201.

${ }^{76}$ Tenże, In epistulam Ioannis ad Parthos tractatus 7, 8, ed. G. Madurini - L. Muscolino - F. Monteverde, NBA 24/2, Roma 1985², 1782. 
miałaby usprawiedliwiać wszystko. Biskup Hippony przypomina tymczasem, że ,amor ipse ordinate amandus est" "77, a więc tylko uporządkowana miłość obdarza człowieka wolnością wobec zewnętrznych praw.

Podsumowując, możemy stwierdzić, że werset Pnp 2, 4, LXX nie doczekał się u Augustyna jakiegoś głębszego opracowania egzegetycznego ${ }^{78}$, a wiele jego myśli związanych z tym fragmentem pojawiało się już u wcześniejszych autorów. Tym niemniej, na uwagę zasługuje podkreślanie przez niego aspektu moralnego (przestrzeganie ,porządku miłości” jest cnotą, a lekceważenie grzechem). Znamienne dla Augustyna jest też dostrzeżenie w ordo caritatis aspektu estetycznego (pochodna ,porządku miłości” jest piękno). Tu i ówdzie pojawiają się też u niego pewne elementy kazuistyki, gdzie na dylematy związane z zachowaniem ordo caritatis udziela on konkretnych i uzasadnionych odpowiedzi.

2. Jan Kasjan. Opat z Marsylii († ok. 435) nie był, jak wiadomo, ani teologiem, ani egzegetą w dzisiejszym rozumieniu. Był raczej nauczycielem duchowości, zatroskanym o rozwój wewnętrzny czytelników swoich pism, głównie mnichów. Ponieważ jednak Słowo Boże, jak podkreślali sami mnisi, było w ich życiu bardziej potrzebne niż pokarm doczesny, Jan Kasjan nie mógł pominąć w swoich dziełach odniesień do Pisma Świętego, które w jego twórczości zajmuje centralne miejsce, o czym świadczy chociażby ponad 1700 cytatów biblijnych, występujących w jego pismach ${ }^{79}$. Jest wśród nich interesujący nas werset Pnp 2, 4, LXX, który pojawia się w jednej z jego Rozmów $w^{80}$, a dokładniej w Rozmowie XVI z abba Józefem $O$ przyjaźni ${ }^{81}$. Rozmowa ta sama w sobie jest już ewenementem, gdyż do czasów Jana Kasjana, żaden z autorów chrześcijańskich nie poświęcił przyjaźni osobnej rozprawy, a następna, której autorem będzie Elred (Aelred) z Rievaulx ( $† 1167)$, pojawi się dopiero w XII wieku! ${ }^{82}$. Powodem „milczenia” pisarzy chrześcijańskich o przyjaźni, wydaje się być przykazanie Jezusa, by kochać wszystkich ludzi, nawet nieprzyjaciół (por. Mt 5, 44), i nie zawężać miłości do wybranych tylko osób, co - zwłaszcza w środowisku mniszym - rozumiano jako zakaz przyjaźni partykularnych. Janowi Kasjanowi należy się więc uznanie, że jako pierwszy w świecie chrześcijańskim, ba w świecie mniszym (!), zmierzył się z zagadnieniem przyjaźni, próbując pogodzić miłość do wszystkich ludzi, nakazaną przez Jezusa, ze „szczególnym uczuciem”

${ }^{77}$ Tenże, De civitate Dei 15, 22, NBA 5/2, 438, tłum. Kornatowski, t. 2, s. 201.

${ }^{78}$ Por. Frank, Geordnete Liebe, s. 26.

${ }^{79}$ Por. K.A. Neuhausen, Zu Cassians Traktat „De amicitia” (Coll. 16), w: Studien zur Literatur der Spätantike, hrsg. Ch. Gnilka - W. Schetter, Antiquitas, 1. Reihe, Band 23, Bonn 1975, 184.

${ }^{80}$ Por. Joannes Cassianus, Collationes Patrum XXIV, éd. E. Pichery, SCh 42, 54, 64, Paris 1955-1959, tłum. L. Wrzoł: Jan Kasjan, Rozmów dwadzieścia cztery, POK 6-7, Poznań 1928-1929; A. Nocoń: Jan Kasjan, Rozmowy z Ojcami, t. 1: Rozmowy I-X, ŹM 28, Kraków 2002; t. 2: Rozmowy XI-XVII, ŹM 70, Kraków 2015.

${ }^{81}$ Por. tamże XVI 14, SCh 54, 234, ŹM 70, 289.

${ }^{82}$ Por. Aelredus Rievallensis, De spiritali amicitia, ed. A. Hoste, CCCM 1, Turnhout 1971, $287-$ 350, thum. M. Wylęgała: Elred z Rievaulx, Przyjaźn duchowa, Kęty 2004. 
okazywanym tylko wybranym. Punktem wyjścia dla niego są różne rodzaje jednej i tej samej miłości, rozlanej w sercach ludzi przez Ducha Świętego (por. Rz $5,5)^{83}$. Pierwszym, najbardziej ogólnym rodzajem, bo obejmującym wszystkich ludzi, nawet nieprzyjaciół, jest miłość określana jako ỏ $\gamma \alpha \dot{\alpha} \pi \eta^{84}$. Drugim, okazywanym już tylko nielicznym, i to posiadającym podobne cnoty lub obyczaje, jest miłość określana jako $\delta ı \alpha ́$ $\theta \varepsilon \sigma ı \varsigma$, choć i ona ma wiele różnych odcieni ${ }^{85}$ :

„Inaczej bowiem miłujemy rodziców, inaczej męża czy żonę, inaczej braci, inaczej dzieci. W każdej z tych kategorii istnieje jeszcze tak wielka rozpiętość uczuć, że nawet miłość rodziców względem dzieci nie bywa jednakowa. Przykładem może być patriarcha Jakub, ojciec dwunastu synów, który choć wszystkich kochał ojcowską miłością, to jednak Józefa darzył szczególnym uczuciem [...]. Nie oznacza to, że ten sprawiedliwy mąż i ojciec, nie obdarzał wielką miłością także pozostałych synów; oznacza tylko, że względem Józefa ojcowskie uczucie było jakby słodsze i bardziej czułe, ponieważ był on typem naszego Pana. To samo możemy przeczytać o Janie Ewangeliście, o którym wyraźnie powiedziano, że był uczniem «którego Jezus miłował» (J 13, 23), choć przecież także pozostałych jedenastu, którzy podobnie jak on zostali wybrani, Jezus otaczał szczególną miłością. [...] A zatem umiłowanie Jana nie oznaczało chłodu wobec pozostałych uczniów, lecz większą i bardziej szczodrą miłość, którą Jan zawdzięczał przywilejowi dziewictwa i cielesnej czystości”"86.

Dla Kasjana nie ma więc sprzeczności między przykazaniem miłości wobec wszystkich ludzi, a szczególnym uczuciem okazywanym niektórym ze względu na podobne obyczaje, wspólne cnoty, zasługi czy otrzymane łaski. Miłość czy przyjaźń wobec tych osób nie oznacza bowiem nienawiści względem pozostałych, a jedynie większe „natężenie” uczucia:

„Coś podobnego czytamy także w Księdze Pieśni nad Pieśniami, gdzie Oblubienica mówi: «Uporządkujcie we mnie miłość» (Pnp 2, 4, LXX). Prawdziwie uporządkowaną miłością jest ta, gdy ktoś nikogo nie nienawidząc, niektórych kocha bardziej z powodu ich zasług. Dalej, gdy darząc miłością wszystkich, wyróżnia tych, których powinien otoczyć szczególnym uczuciem, a pośród tych, którzy są mu wyjątkowo drodzy i kocha ich bardzo mocno, wybiera jeszcze takich, których obdarza największą miłością" ${ }^{87}$.

Cechą charakterystyczną komentarza Jana Kasjana do Pnp 2, 4, LXX (pomijanego niestety w najważniejszych opracowaniach dotyczących tego werse$\mathrm{tu}^{88}$ ), jest to, że swoje rozumienie „porządku miłości” oparł nie na stopniach,

\footnotetext{
${ }^{83}$ Por. Joannes Cassianus, Collationes Patrum XVI 13, SCh 54, 233, ŹM 70, 286.

${ }^{84}$ Por. tamże XVI 14, SCh 54, 233, ŹM 70, 287.

${ }^{85}$ Por. tamże.

${ }^{86}$ Tamże, SCh 54, 233-234, ŹM 70, 287-288.

${ }^{87}$ Tamże, SCh 54, 234, ŹM 70, 289.

${ }^{88}$ Por. np. Frank, Geordnete Liebe, s. 15-30.
} 
choć taki tytuł posiada jego rozważanie (De gradibus caritatis $^{89}$ ), ale na różnych rodzajach jednej i tej samej miłości, nawiązując tym samym do orygenesowskiego rozróżnienia między miłością ogólną a szczegółową. Ordo caritatis miałby więc u niego strukturę nie tyle wertykalna, co horyzontalną, którą na własny użytek moglibyśmy nazwać struktura ,heliocentryczną”. W ujęciu tym wszyscy ludzie, zanurzeni w jednej i tej samej miłości Bożej, jak planety należące do jednego układu słonecznego, podlegaliby wzajemnemu przyciąganiu, tym silniejszemu im duchowo i fizycznie (przez pokrewieństwo) byliby sobie bliscy.

3. Apponiusz. Powstały, prawdopodobnie w 1. poł. V w., Komentarz do Pieśni nad Pieśniami Apponiusza ${ }^{90}$, jest zarazem pierwszym łacińskim komentarzem do tej księgi zachowanym w całości do naszych czasów ${ }^{91}$. Mimo że jego autor korzystał obficie z dorobku wcześniejszych pisarzy, zwłaszcza Orygenesa i Grzegorza z Nyssy, dzieło to posiada wiele cech oryginalnych: autor widzi na przykład w Pieśni nad Pieśniami jedno wielkie proroctwo o wcieleniu Syna Bożego i jedno wielkie wezwanie do doskonałości ${ }^{92}$.

Jeśli chodzi o werset Pnp 2, 4, LXX, Apponiusz uważa, że „dom wina” to wieloraka mądrość Boża Starego Testamentu, uporządkowana następnie światłem Chrystusowego objawienia ${ }^{93}$. To samo światło porządkuje też miłość chrześcijanina ${ }^{94}$ : najpierw względem Boga, który „musi być nazwany Ojcem, w którym zawsze jest Syn, jak słowo w głosie; po drugie Synem, w którym zawsze jest Ojciec; i po trzecie Duchem Swiętym, który pochodzi w rzeczywistości z głosu i słowa, z Ojca i Syna" ${ }^{95}$. Ten jeden Bóg w trzech Osobach, połączonych relacjami przypominającymi naturę głosu i słowa (bez żadnej jednak nierówności czy podporządkowania ${ }^{96}$ ), powinien być miłowany z całego serca, z całej duszy i z wszystkich sił (por. np. Pwt 6, 5) ${ }^{97}$. Apponiusz widzi bowiem związek między trojakim sposobem miłowania Boga, a trzema Osobami w Trójcy Świętej ${ }^{98}$.

\footnotetext{
${ }^{89}$ Por. Joannes Cassianus, Collationes Patrum XVI 14, SCh 54, 222, ŹM 70, 287.

${ }^{90}$ Por. Apponius, In Canticum Canticorum Expositio, éd. B. de Vregille - L. Neyrand, SCh 420, 421, 430, Paris 1997-1998.

${ }^{91}$ Por. S. Strękowski, „Pieśń nad Pieśniami” w interpretacji Aponiusza, VoxP 32 (2012) t. 57, 603 .

${ }^{92}$ Por. tamże, s. 604-605 i 612.

${ }^{93}$ Por. Apponius, In Canticum Canticorum Expositio III 38, SCh 420, 342-344, w. 645-660; B. de Vregille - L. Neyrand, Introduction, w: SCh 420, 63.

${ }^{94}$ Por. tamże III 41, SCh 420, 348, w. 707: „Ordinavit ergo Dei Filius in Ecclesia sua caritatem”.

${ }^{95}$ Tamże III 39, SCh 420, 344-346, w. 661-666, tłum. L. Lach-Bartlik, w: tenże, Terminologia trynitarna w ,Expositio in Canticum Canticorum” Apponiusza (Ksieggi I-III), VoxP 32 (2012) t. 57, 388, nota 23. Por. de Vregille - Neyrand, Introduction, s. 79-80.

${ }^{96}$ Por. Lach-Bartlik, Terminologia trynitarna, s. 388.

${ }^{97}$ Por. Apponius, In Canticum Canticorum Expositio III 39, SCh 420, 344-346, w. 661-669.

${ }^{98}$ Por. de Vregille - Neyrand, Introduction, s. 81, nota 1.
} 
W „domu wina” uporządkowana też zostaje miłość do ludzi. Według autora komentarza każdy człowiek posiada ,jakoś miłość (quamlibet caritatem)", ale tę „prawdziwa, doskonałą i uporządkowaną (veram, perfectamque et ordinatam)" posiadająjedynie ci, którzy kierując się umiłowaniem Bożego prawa okazali się godni wejść w jego zrozumienie i posiąść miłość uporządkowaną ${ }^{99}$, gdyż:

„W inny sposób (alio ordine) należy kochać Boga, który według słów Apostoła pierwszy nas umiłował (por. 1J 4, 19), i który w Chrystusie obdarzył nas pełnią miłości, a w inny sposób rodziców, bez których by nas nie było. W inny sposób wiernego przyjaciela, a w inny ukochanego syna. W inny sposób własnego brata, a w inny swoją żonę. W inny sposób sługa powinien kochać swego pana, a w inny pan swego sługę. W inny sposób należy okazywać miłość współobywatelowi, a w inny przybyszowi; w inny możnowładcy, a w inny kapłanowi; w inny, wreszcie, krewnym, a w inny znajomym"100.

Uporządkowana miłość obejmuje także uczynki miłosierdzia:

„Udzielić pomocy biednemu, choremu lub przybyszowi nie dla zyskania ludzkiej chwały, lecz z powodu wiecznej nagrody jest znakiem uporządkowanej miłości. Pocieszać płaczących i skrzywdzonych niesłusznym wyrokiem, odwiedzać chorych i uwięzionych, jest znakiem uporządkowanej miłości. W mówieniu prawdy nie bać się nikogo, nieumiejętnych miłosiernie pouczać, pysznych szczerze upominać, jest znakiem uporządkowanej miłości”101.

Niestety, nie wszyscy, którzy nazywają się chrześcijanami, weszli - zdaniem Apponiusza - do owego ,domu wina”, to znaczy nie wszyscy posiedli ową mądrość owocująca ,„porządkiem miłości”, dostępną tylko tym, którzy jak św. Paweł dla pozyskania Chrystusa wszystko uznali za stratę (por. Flp 3, 8) ${ }^{102}$. Nieznajomość ,porządku miłości” może tymczasem odciaggać chrześcijanina od znoszenia różnorodnych ucisków dla imienia Chrystusa, a czasem nawet pozbawić go korony męczeństwa ${ }^{103}$.

Werset Pnp 2, 4, LXX, jak zauważyliśmy, jest więc postrzegany przez Apponiusza całkowicie przez pryzmat nauczania Jezusa, który objawił wierzącym nie tylko naukę o „porządku miłości” w Trójcy Świętej, ale pouczył ich również jak miłować Boga i bliźniego. Wśród kategorii osób objętych miłością uporządkowaną pojawia się u niego, podobnie jak u Kasjana, ,przyjaciel”, oraz - po raz pierwszy wśród omawianych autorów - współobywatel (civis) i przybysz (peregrinus). Charakterystyczne dla Apponiusza jest również odczytywanie wersetu Pnp 2, 4, LXX przez pryzmat wezwania do doskonałości, stąd jego postulat, aby i uczynki miłosierdzia były w człowieku

\footnotetext{
${ }^{99}$ Por. Apponius, In Canticum Canticorum Expositio III 39, SCh 420, 346, w. 675-680.

${ }^{100}$ Tamże, SCh 420, 348, w. 684-693, thum. własne.

${ }^{101}$ Tamże, SCh 420, 348, w. 693-700, tłum. własne.

${ }^{102}$ Por. tamże III 41, SCh 420, 350, w. 713-719, tłum. własne.

${ }^{103}$ Por. tamże III 40, SCh 420, 348, w. 700-707.
} 
uporządkowane, to znaczy, wykonywane z miłości do Boga, a nie dla próżnej chwały. Novum jego komentarza jest wreszcie końcowa ,gorzka refleksja”, że nie wszyscy chrześcijanie posiedli prawdziwą mądrość, owocującą ,porządkiem miłości”, oraz, że mądrość ta musi być zawsze okupiona bólem („,kto przysparza wiedzy - przysparza i cierpień" - Koh 1, 18), a jednak to właśnie w tym cierpieniu, dosłownie w tej ,chorobie” (por. Pnp 2, 5), która pozbawia duszę „sił do grzeszenia”, rodzi się owa błogosławiona, bo uporządkowana miłość do Boga i do bliźniego - pociesza Apponiusz ${ }^{104}$.

Na marginesie omawiania komentarza Apponiusza do wersetu Pnp 2, 4, LXX, warto zwrócić uwagę na jeszcze jeden, niezwiązany bezpośrednio z tematem, szczegół. Otóż, sam autor, jak wiadomo, jest postacią dość tajemniczą: wokół jego biografii i czasu powstania komentarza toczy się wciąż dyskusja. Zasadniczo przyjmuje się, że jego dzieło powstało w Italii (w Rzymie?), w 1. poł. V w., lecz nie brak uczonych, którzy uważają, że zostało napisane w Irlandii i to w wieku VII ${ }^{105}$. Kwestii tej nie da się obecnie rozstrzygnąć, warto jednak zwrócić uwagę, że jedynie w dziełach Apponiusza i Jana Kasjana znajdujemy słowa Pisma Świętego w brzmieniu nie występującym u innych autorów $^{106}$. Oczywiście, nie można na tej podstawie wyciagać wniosku, że Apponiusz i Kasjan znali się i wymieniali rękopisami, ale gdyby przyjać, że żyli w tym samym czasie byłoby to dalece prawdopodobne, a sama nauka zyskałaby, mały wprawdzie, ale za to jeszcze jeden argument, za powstaniem komentarza Apponiusza w 1. poł. V wieku.

$* * *$

Podsumowując komentarze poszczególnych autorów do wersetu Pnp 2, 4 , LXX zauważamy, że są one w znacznej mierze ze sobą zgodne i nawiązują mniej lub bardziej do Orygenesowych homilii i komentarza na temat Pieśni nad Pieśniami, stanowiących fundament dla wszystkich późniejszych interpretacji ${ }^{107}$. Zasadniczo więc omawiani przez nas Ojcowie zgadzają się, że każdy człowiek coś lub kogoś kocha, a sama miłość jest czymś dobrym. Niestety, nawet rzeczy z natury dobre, jeśli używane są źle, prowadzą do grzechu, co

\footnotetext{
${ }^{104}$ Por. tamże III 42, SCh 420, 350-352, w. 720-740.

${ }^{105}$ Por. S. Strękowski, „Pieśń nad Pieśniami” w interpretacji Aponiusza, s. 603.

${ }^{106}$ Por. Mt 16, 17: „Beatus es, Simon Bar Iona, quia caro et sanguis non revelavit tibi sed Pater meus, qui in caelis est"; Apponiusz (In Canticum Canticorum Expositio II 8, SCh 420, 240, w. 153 155) i Jan Kasjan (De incarnatione Domini III 13, PL 50, 69B) jako jedyni zamiast „Pater meus”, zapisali „Spiritus Patris mei”. Podobnie jeśli chodzi o werset Ct 3, 1: „In lectulo meo per notes quaesivi, quem diligit anima mea; quaesivi illum et non inveni", jedynie ci dwaj autorzy dodali do niego słowa: ,et vocavi eum et non respondit mihi”, por. Apponius, In Canticum Canticorum Expositio V 7, SCh 421, 74, w. 101-103; Joannes Cassianus, Collationes Patrum XIII 13, SCh 54, 168. Zob. również B. de Vregille - L. Neyrand, w: Apponius, In Canticum Canticorum Expositio, SCh 420, 240-241, nota 2, oraz SCh 421, 74, nota 1 .

${ }^{107}$ Por. Pétré, Ordinata caritas, s. 51.
} 
często ma miejsce w przypadku miłości, gdyż wielu kocha nie to, co powinno, a jeśli już kocha to, co powinno, to kocha nadmiernie lub niedostatecznie, czyli w sposób nieuporządkowany. Już Stary Testament przypominał więc człowiekowi o ,porządku miłości”, ale w pełni zrozumiały porządek ten stał się dopiero w świetle Chrystusowego objawienia, dzięki któremu człowiek nie tylko dowiedział się o „,porządku miłości” w Trójcy Świętej, ale otrzymał również właściwą miarę miłości Boga i bliźniego („,Będziesz miłował Pana Boga twego całym swoim sercem..." - por. Mt 22, 37. 39). Właśnie przez pryzmat Chrystusowego przykazania miłości patrzyli na werset Pnp 2, 4, LXX, wszyscy wspominani przez nas autorzy, podkreślając absolutne pierwszeństwo miłości względem Boga przed kimkolwiek innym. Tylko zachowanie tego porządku, tak jak czynili to święci, gwarantuje postęp na drodze doskonałości. Odnośnie miłości bliźnich Ojcowie wskazywali natomiast na dwa kryteria ,porządku”: kryterium pokrewieństwa i kryterium zasługi. W świetle tego pierwszego: żona, rodzice, dzieci, mają pierwszeństwo przed innymi domownikami, w świetle zaś drugiego, osoby wyróżniające się charakterem, uczynkami, wiedzą, przede wszystkim jednak ci, którzy pouczają i oświecają ludzkie dusze, ukazując im drogę zbawienia, zasługują na miłość szczególną.

W postrzeganiu „porządku miłości” występują pewne różnice między Ojcami Wschodu i Zachodu. Ojcowie Wschodni zaraz po Bogu nakazywali miłować tych, którzy zrodzili innych w Chrystusie (por. 1Kor 4, 15), czyli tych, którzy ukazali innym drogę zbawienia i wspomagali ich na niej. Dopiero po nich nakazywali miłować rodziców, czyli tych, którzy zrodzili w ciele. To stawianie na pierwszym miejscu wiary sprawiło, że niektórzy spośród Ojców Wschodnich widzieli nawet różnicę w okazywaniu miłości rodzicom wierzącym i niewierzącym. Charakterystyczne dla Ojców Wschodnich jest również to, że tylko oni zastanawiali się na czym polegałaby uporządkowana miłość wobec nieprzyjaciół, i odpowiadali, że: a) na wyzbyciu się wobec nich nienawiści; b) na różnym traktowaniu ich w zależności od tego czy zachowują Boże przykazania czy też nie zachowują; c) na odpłacaniu im dobrem za zło.

Ojcowie Zachodni z kolei, mocniej podkreślali aspekt moralny „porządku miłości” przypominając, że jego przestrzeganie jest cnota, a naruszanie grzechem. W związku z tym, częściej też pojawiały się w ich wypowiedziach pewne elementy kazuistyki, odnoszące się głównie do zachowania „porządku miłości” w czasie prześladowań: miłość do bliskich - przypominali - nie może stać nigdy wyżej niż miłość do Jezusa. Nowością w komentarzach Ojców Zachodnich jest również refleksja nad ,porządkiem miłości” w Trójcy Świętej oraz pojawienie się nowych grup ludzi objętych „porządkiem”: przyjaciół, współobywateli, przybyszów. Niektórzy z Ojców Zachodnich aplikowali również „porządek miłości” do uczynków miłosierdzia oraz zwracali uwagę na aspekt estetyczny ordo caritatis, podkreślając, że pochodną wszelkiego porządku jest piękno.

Wracając zaś do zasygnalizowanego na wstępie problemu emigracji i obcokrajowców, należy stwierdzić, że żaden z sześciu Ojców nie podjął rozważań 
na ten temat, co związane było, jak można się jedynie domyślać, z tym, że większość ludzi ówczesnego świata żyła w jednym i tym samym państwie, a działalność pisarska kilku spośród Ojców przypadła na czas przed najazdami barbarzyńskich plemion i wędrówką ludów. Słowa „współobywatel” (civis) i „przybysz” (peregrinus), pojawiają się więc dopiero w komentarzu Apponiusza, który stwierdził jedynie, że „w inny sposób należy okazywać miłość współobywatelowi, a w inny przybyszowi”.

Post scriptum. Werset 2, 4b Pieśni nad Pieśniami, który w języku hebrajskim brzmi dosłownie: „sztandarem jego nade mną jest miłość”108, oddano

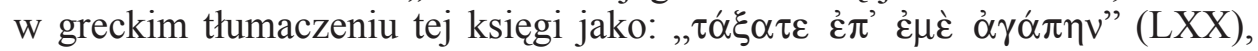
co Ojcowie Kościoła, tak greccy jak i łacińscy, rozumieli jako wezwanie do „uporządkowania miłości” (ordinate in me caritatem). Niezależnie od tego, czy różnica między tekstem oryginalnym a interpretacją Ojców wynikała z ich niedostatecznej znajomości języka hebrajskiego, czy też była świadomą modyfikacją ${ }^{109}$, wynikającą np. z faktu, że ruchem sztandarów w ówczesnym świecie utrzymywano porządek szyków wojskowych, faktem jest, że w całej tradycji wczesnochrześcijańskiej właśnie w ten sposób, powtórzmy, jako wezwanie do „uporządkowania miłości”, odczytywano te słowa. Rodzi się więc pytanie: czy za cenę zbliżenia do tekstu hebrajskiego zasadne jest dzisiaj tłu-

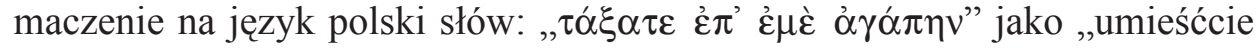
przy mnie mą miłość", jak w wydanym niedawno pierwszym polskim przekładzie Septuaginty ${ }^{110}$, czy jako „umieśćcie nade mną miłość”, jak w przypadku niektórych polskich tłumaczeń pism Ojców Kościoła ${ }^{111}$, wbrew całej niejako tradycji patrystycznej, gdzie jednoznacznie odczytywano te słowa w kontekście przestrzegania pewnego ,porządku”, tworząc tym samym fundament do zbudowania chrześcijańskich zasady ordo caritatis $^{112}$.

\section{"YOU SET CHARITY IN ORDER IN ME" (SONG 2:4, LXX) \\ IN THE EXEGESIS OF SELECTED AUTHORS OF THE EAST AND WEST}

\section{(Summary)}

"You set charity in order in me" (Song 2:4, LXX) is one of the most fundamental biblical texts for the concept of the ordo caritatis. The Author seeks to examine how this text was read in the East and West, analysing the commentary of three Greek authors (Origen, Gregory of Nyssa and Theodoret of Cyrus),

${ }^{108}$ Por. Pismo Święte Starego i Nowego Testamentu, Poznań - Warszawa 1988, 748.

${ }^{109}$ Por. Frank, Geordnete Liebe, s. 15, nota 2.

${ }^{110}$ Por. Septuaginta czyli Biblia Starego Testamentu wraz z księgami deuterokanonicznymi i apokryfami, tłum. R. Popowski, Warszawa 2013, 1082.

${ }^{111}$ Por. np. Grzegorz z Nyssy, Homilie do Pieśni nad Pieśniami, s. 74.

112 Por. np. Pétré, Ordinata caritas, s. 41; Frank, Geordnete Liebe, s. 15. 
and three Latin authors (Augustine of Hippo, John Cassian and Apponius). There commentaries, he notes, agree with one another for the most part, and refer more or less to Origen's exegesis of this verse. However, some differences can be noted. The Eastern Fathers, for example, hold that, in the order of charity, the criterion of merit is more important than the criterion of blood relationship; that is to say, the greater love is to be shown to those who have been born in Christ (cf. 1Cor 4:15) over those born of the flesh. Only the Eastern Fathers explore what the ordo caritatis means also in relation to one's enemies.

The Western Fathers, for their part, tend to underline the moral aspect of the ordo caritatis, insofar as upholding that order is virtue, while infringing it is sin. In this regard, a casuistic approach can occur in their commentary more frequently than in those of the Eastern Fathers. The novelty of the commentaries of the Western Fathers is also found in their reflection on the ordo caritatis within the Holy Trinity, as well as the manner in which they expand the embrace of this order to other categories of people: friends, fellow citizens, strangers. Some of the Western Fathers (Apponius) apply the ordo caritatis not only to people but also to works of mercy, while others (Augustine) bring out the aesthetic element in the ordo caritatis, noting that the effect of order of any kind, including the order of charity, is beauty.

Key words: Song of Songs, the order of charity (ordo caritatis), Origen, Gregory of Nyssa, Theodoret of Cyrus, Augustine of Hippo, John Cassian, Apponius.

Słowa kluczowe: Pieśń nad Pieśniami, porządek miłości (ordo caritatis), Orygenes, Grzegorz z Nyssy, Teodoret z Cyru, Augustyn, Jan Kasjan, Apponiusz.

\section{BIBLIOGRAFIA}

\section{Źródła}

Aelredus Rievallensis, De spiritali amicitia, ed. A. Hoste, CCCM 1, Turnhout 1971, 287350, thum. M. Wylęgała: Elred z Rievaulx, Przyjaźn duchowa, Kęty 2004.

Apponius, In Canticum Canticorum Expositio, éd. B. de Vregille - L. Neyrand, SCh 420, 421, 430, Paris 1997-1998.

Augustinus, De civitate Dei libri XXII, ed. A. Trapè - R. Russell - S. Cotta - D. Gentili,

NBA 5/1, Roma 1978, ed. D. Gentili - A. Trapè, NBA 5/2, Roma 1988, tłum. W. Kornatowski: Święty Augustyn, O państwie Bożym. Przeciw poganom ksiag XXII, t. 1-2, Warszawa 1977.

Augustinus, In epistulam Ioannis ad Parthos tractatus, ed. G. Madurini - L. Muscolino F. Monteverde, NBA 24/2, Roma $1985^{2}$.

Augustinus, Sermones, NBA 29-35, Roma 1979-2001.

Gregorius Nyssenus, Homiliae in Canticum canticorum, ed. H. Langerbeck, GNO 6, Leiden 1960, thum. M. Przyszychowska: Grzegorz z Nyssy, Homilie do Pieśni nad Pieśniami, ŹMT 43, Kraków 2007.

Joannes Cassianus, Collationes Patrum XXIV, éd. E. Pichery, SCh 42, 54, 64, Paris 19551959, thum. L. Wrzoł: Jan Kasjan, Rozmów dwadzieścia cztery, POK 6-7, Poznań 1928-1929; A. Nocoń: Jan Kasjan, Rozmowy z Ojcami, t. 1: Rozmowy I-X, ŹM 28, Kraków 2002; t. 2: Rozmowy XI-XVII, ŹM 70, Kraków 2015.

Joannes Cassianus, De incarnatione Domini contra Nestorium libri VII, PL 50, 9-270. 
Origenes, Commentarium in Canticum canticorum, éd. L. Brésard - H. Crouzel - M. Borret, SCh 375-376, Paris 1991-1992, thum. S. Kalinkowski, w: Orygenes, Komentarz do „Pieśni nad Pieśniami”. Homilie o „Pieśni nad Pieśniami”, Kraków 1994, 7-189.

Origenes, Homiliae in Canticum canticorum, éd. O. Rousseau, SCh 37bis, Paris 20072, thum. S. Kalinkowski, w: Orygenes, Komentarz do „Pieśni nad Pieśniami”. Homilie o „Pieśni nad Pieśniami”, Kraków 1994, 193-227.

Pismo Święte Starego i Nowego Testamentu, Poznań - Warszawa 1988.

Septuaginta czyli Biblia Starego Testamentu wraz z księgami deuterokanonicznymi i apokryfami, thum. R. Popowski, Warszawa 2013.

Theodoretus Cyrensis, Commentarium in Canticum canticorum, PG 81, 27-214.

\section{Opracowania}

BARdSKI K., „Napoję cię winem korzennym, moszczem z granatów” (Pnp 8, 2b). Pragnienie Oblubieńca $w$ świetle starożytnych i średniowiecznych komentarzy do Pieśni nad Pieśniami, VV 5 (2004) 145-169.

BARdski K., Duchowa interpretacja Pieśni nad Pieśniami w tradycji żydowskiej i chrześcijańskiej, CT 78 (2008) nr 4, 105-111.

Bartoszek A., Porzadek w miłości, „Gość Niedzielny” 93 (2016) nr 27, $28-29$.

DraczKowski F., Patrologia, Pelplin - Lublin 1998.

FranK K.S., Geordnete Liebe. Cant 2, 4 b in der patristischen Auslegung, „Wissenschaft und Weisheit" 49 (1986) 15-30.

Lach-Bartlik L., Terminologia trynitarna $w$, Expositio in Canticum Canticorum” Apponiusza (Księgi I-III), VoxP 32 (2012) t. 57, 379-397.

Neuhausen K.A., Zu Cassians Traktat „De amicitia” (Coll. 16), w: Studien zur Literatur der Spätantike, hrsg. Ch. Gnilka - W. Schetter, Antiquitas, 1. Reihe, Band 23), Bonn 1975, 181-218.

PÉTRÉ H., Ordinata caritas. Un enseignement d'Origène sur la charité, RSR 42 (1954) 40-57.

Pietras H., L'amore in Origene, SEA 28, Roma 1988.

Przyszychowska M., Wstęp, w: Grzegorz z Nyssy, Homilie do Pieśni nad Pieśniami, ŹMT 43, Kraków 2007, 5-11.

Starowieyski M., Tradycje biblijne, Kraków 2011.

StręKowski S., „Pieśń nad Pieśniami” w interpretacji Aponiusza, VoxP 32 (2012) t. 57, 601-612.

Vregille B. de - Neyrand L., Introduction, w: SCh 420, Paris 1997, 15-122. 


\section{ANEKS}

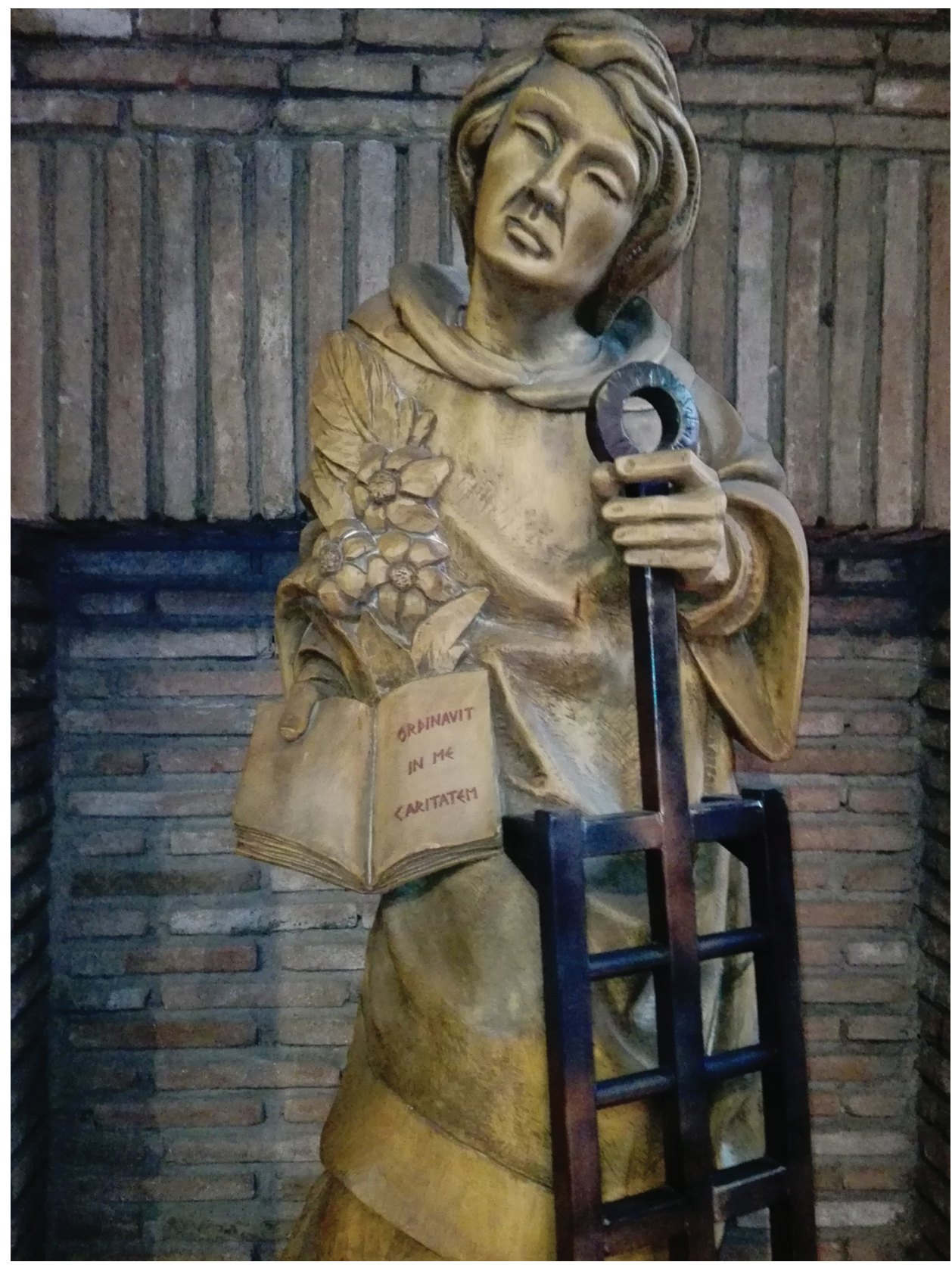

„Ordinavit in me caritatem” (por. Pnp 2, 4, LXX), w ręku św. Wawrzyńca, w rzymskim kościele pod jego wezwaniem (fot. ks. A. Nocoń). 
